\title{
Galanin Inhibits Continuous and Phasic Firing in Rat Hypothalamic Magnocellular Neurosecretory Cells
}

\author{
Sophie Papas and Charles W. Bourque \\ Centre for Research in Neuroscience, Montreal General Hospital Research Institute and McGill University, Montreal, \\ Quebec, Canada H3G 1 A3
}

The effects of galanin (GAL) on magnocellular neurosecretory cells (MNCs) were examined during microelectrode recordings from supraoptic neurons in superfused hypothalamic explants. Application of the full-length peptide $\left(G A L^{1-29}\right)$ or of the $\mathrm{N}$-terminal fragment $\mathrm{GAL}^{1-16}$ produced reversible membrane hyperpolarization with an $\mathrm{IC}_{50}$ near $10 \mathrm{nM}$. These effects were associated with an increase of membrane conductance, with a reversal potential near $-70 \mathrm{mV}$, and were not blocked by tetrodotoxin, indicating that the receptors mediating these effects are located postsynaptically. Hyperpolarizing responses were also observed in response to the GAL-like chimeric ligands M35 and M40, suggesting that these behave as partial agonists at galanin receptors. The reversal potential of the GAL-mediated effect was unaffected by reducing extracellular chloride or by intracellular chloride injection, indicating that the effects of galanin are not mediated by modulation of chloride conductances. In contrast, reducing the external concentration of potassium ions from 3 to $1 \mathrm{~mm}$ shifted the reversal potential of the responses to $-85 \mathrm{mV}$, suggesting the involvement of a potassium conductance. When tested on spontaneously active MNCs, the hyperpolarizing effects of galanin were associated with a suppression of firing in both continuously active and phasically active neurons. Inhibition of phasic bursts was mediated both through the inhibitory effects of the hyperpolarization and through a GAL-mediated inhibition of the depolarizing afterpotential that is responsible for the production of individual bursts. These results suggest that galanin may be a potent endogenous modulator of firing pattern in hypothalamic neuroendocrine cells.

Key words: galanin; supraoptic nucleus; vasopressin; oxytocin; bursting activity; neurosecretory neurons; depolarizing afterpotentials
The peptide hormones vasopressin and oxytocin are synthesized within individual hypothalamic magnocellular neurosecretory cells (MNCs). Axons emerging from MNC somata project to the neurohypophysis where peptides are released into the circulation on the arrival of action potentials into nerve terminals (Dreif uss et al., 1971). Because these terminals cannot sustain intrinsic repetitive firing (Bourque, 1990), neurosecretion at this locus is primarily regulated through changes in electrical activity initiated at the soma. Previous studies have shown that neurohypophysial peptide release per action potential increases with firing rate (Dreifuss et al., 1971) and is maximized by the generation of phasic bursting activity (Dutton and Dyball, 1979; Bicknell and Leng, 1981; Bicknell et al., 1982). The regulation of firing rate and pattern in MNCs is therefore a primary determinant of neurohypophysial function.

In mammals, the secretion of vasopressin, the antidiuretic hormone, is enhanced by hyperosmolality and reduced by hypotonicity of the blood (Striker and Verbalis, 1986; Verbalis and Dohanics, 1991). Oxytocin, in turn, is well known for its role in promoting uterine contractions (Summerlee, 1981) and milk ejection (Wakerley and Lincoln, 1973). In the rat, however, oxytocin is also potently natriuretic (Verbalis et al., 1991), and its release is osmotically regulated in a manner analogous to that of vaso-

Received April 11, 1997; revised May 27, 1997; accepted May 29, 1997.

This work was supported by an operating grant from the Medical Research Council of Canada to C.W.B. and by Medical Research Council fellowship and scientist awards to S.P. and C.W.B.

Correspondence should be addressed to Dr. Charles W. Bourque, Division of Neurology, Montreal General Hospital, 1650 Cedar Avenue, Montreal, Quebec, Canada H3G $1 \mathrm{~A} 4$.

Copyright (C) 1997 Society for Neuroscience $0270-6474 / 97 / 176048-09 \$ 05.00 / 0$ pressin (Striker and Verbalis, 1986; Verbalis and Dohanics, 1991). Neurohypophysial hormone release, therefore, plays a central role in systemic osmoregulation.

Recent studies indicate that galanin (GAL), a 29 amino acid peptide first isolated from gut (Tatemoto et al., 1983), is present in fibers coursing through hypothalamic nuclei containing MNCs (Melander et al., 1986; Levin et al., 1987) as well as in MNCs themselves (Rökaeus et al., 1988; Gaymann and Martin, 1989; Skofitsch et al., 1989). Moreover, mRNA coding for a homolog of the human galanin receptor (Habert-Ortoli et al., 1994) has recently been detected in MNC somata (Gustafson et al., 1996), indicating that centrally released GAL may regulate MNCs directly. Functional support for GAL-mediated regulation of the hypothalamo-neurophypophysial axis comes from the finding that intracerebroventricular inf usion of GAL in vivo reduces the content of mRNA coding for vasopressin in MNCs (Landry et al., 1995). Moreover, intracerebroventricular infusions of the peptide inhibit the release of both oxytocin (Bjorkstrand et al., 1993) and vasopressin (Kondo et al., 1991; Kondo et al., 1993). Although the effects of GAL on somatic mRNA content might contribute to the long-term attenuation of vasopressin release, inhibitory effects on neurohypophysial secretion are detectable within minutes after GAL administration, suggesting that acute physiological effects may be mediated via changes in electrical activity.

Although the above findings support a role for GAL in the regulation of the hypothalamo-neurohypophysial axis, the cellular basis for its action as a central neuromodulator of MNCs has not been described. In this study, we examined the electrophysiogical effects of GAL on MNCs in the supraoptic nucleus of the rat. Our results indicate that MNCs express membrane receptors 
A

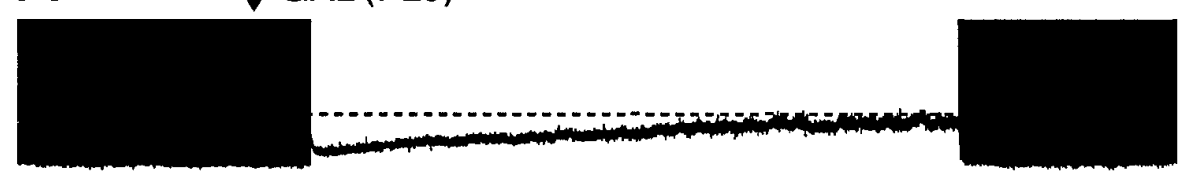

B

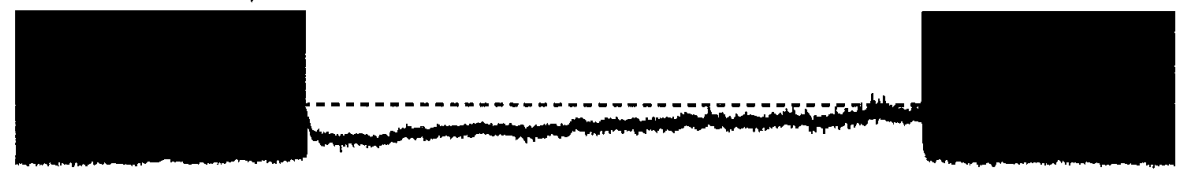

$\mathrm{C} \quad+\mathrm{M} 40$

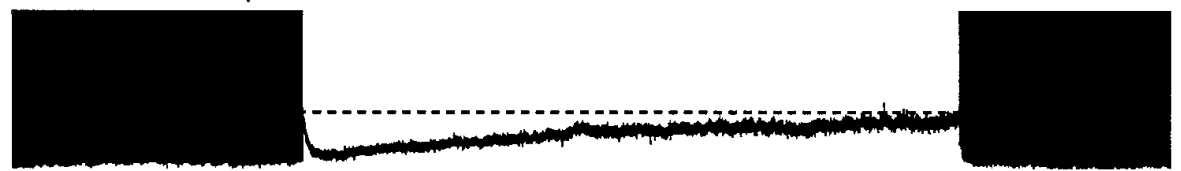

$20 \mathrm{mV}$

$30 \mathrm{~s}$
Figure 1. Effects of bolus infusion of GAL receptor ligands on continuous activity. Shown are intracellular recordings (truncated at greater than $-35 \mathrm{mV}$ ) of membrane potential from MNCs in the supraoptic nucleus of rat hypothalamic explants. The arrow above each trace shows when a $10 \mathrm{sec}$ infusion was initiated to evoke a rapid increase in the concentration of $A, \mathrm{GAL}^{1-29}$ (1 $\mu \mathrm{M}) ; B$, GAL ${ }^{1-16}(2.5 \mu \mathrm{M})$; and $C$, M40 (1 $\left.\mu \mathrm{M}\right)$. Note that in all cases the infusion resulted in a reversible hyperpolarization and inhibition of firing. Similar infusions of ACSF were without effect (not shown). for GAL and that activation of these receptors inhibits patterned firing.

\section{MATERIALS AND METHODS}

Preparation of superfused rat hypothalamic explants. Explants were prepared as described previously (Bourque, 1988; 1989). Briefly, male Long-Evans rats $(150-300 \mathrm{gm})$ were killed by decapitation using a rodent guillotine (Stoelting), and their brains were removed from the cranial vault. A block of tissue $(8 \times 8 \times 2 \mathrm{~mm})$ constituting the basal hypothalamus was excised using a razor blade and pinned, ventral side up, to the Sylgard base of a temperature-controlled $\left(33-35^{\circ} \mathrm{C}\right)$ superfusion chamber. Within 2 min of decapitation, explants were being superfused $(0.5-1 \mathrm{ml} / \mathrm{min})$ with an oxygenated $\left(95 \% \mathrm{O}_{2} / 5 \% \mathrm{CO}_{2}\right)$ artificial CSF (ACSF; see below) delivered via a Tygon tube placed over the medial tuberal region. Membranes covering the ventral surface of the supraoptic nucleus were removed using fine forceps, and a cotton wick was placed at the rostral tip of the explant to facilitate drainage of ACSF.

Solutions and drugs. The ACSF, pH $7.4(295 \pm 1 \mathrm{mOsm} / \mathrm{kg})$, comprised (in mM): $\mathrm{NaCl}, 126 ; \mathrm{MgCl}_{2}, 1.3 ; \mathrm{KCl}, 3 ; \mathrm{NaHCO}_{3}, 26 ; \mathrm{NaH}_{2} \mathrm{PO}_{4}$, 1; glucose, 10; and $\mathrm{CaCl}_{2} 2$ (all from Fisher Scientific, Pittsburgh, PA). Where indicated, the ACSF was supplemented with with $0.3 \mu \mathrm{M}$ tetrodotoxin (Sigma, St. Louis, MO). Low-chloride ACSF was prepared by substituting $63 \mathrm{~mm} \mathrm{Na}_{2} \mathrm{SO}_{4}$ for $\mathrm{NaCl}$ and by adding mannitol (Fisher Scientific) to adjust the osmotic pressure to $295 \pm 1 \mathrm{mOsm} / \mathrm{kg}$. Changes in the concentration of extracellular $\mathrm{K}^{+}$were achieved by isomolar exchange between $\mathrm{KCl}$ and $\mathrm{NaCl}$.

Peptides used in these experiments included galanin 1-29, the $\mathrm{N}$-terminal fragment galanin 1-16 (both from Peninsula Laboratories Inc., Belmont, CA), and the chimeric galanin receptor ligands M35 and M40, which were purchased from Drs. T. Bartfai and U. Langel (Department of Neurochemistry and Neurotoxicology, Stockholm University, Stockholm, Sweden). All peptides were dissolved in ACSF (20-500 $\mu \mathrm{M})$ and stored at $-20^{\circ} \mathrm{C}$. Before each experiment, aliquots of peptide stocks were further diluted into oxygenated ACSF. To examine the effects of the peptides during prolonged $(>60 \mathrm{sec})$ applications, drugs were dissolved in ACSF and bath-applied via a T junction leading to the main superfusion line. Briefer applications were achieved by infusing a concentrated bolus $(5-100 \mu \mathrm{l})$ through a small catheter inserted near the end of the superfusion tube. The concentration of drugs applied using this method reaches a peak within $10-15 \mathrm{sec}$ and subsequently declines over a period of 20-40 sec (Bourque, 1989).

Electrophysiology. Intracellular recordings were obtained using sharp micropipettes prepared from glass capillary tubes $(1.2 \mathrm{~mm}$ outer diame- ter) pulled on a Flaming-Brown P87 puller (Sutter Instruments Co., Novato, CA). These were filled with $2 \mathrm{~m}$ potassium acetate or, where specified in the text, using a solution comprising $1 \mathrm{M} \mathrm{KCl}$ and $1 \mathrm{M}$ potassium acetate. The DC resistance of these microelectrodes, measured with respect to a chlorided silver wire immersed in ACSF, was $70-150 \mathrm{M} \Omega$. Recordings of membrane voltage were obtained through an Axoclamp 2A amplifier (Axon Instruments Inc., Foster City, CA). Signals acquired during each experiment were displayed on a chart recorder and digitized (44 KHz; Neuro Data Instruments Corp., Delaware Water Gap, PA) for storage on videotape. Current pulses were delivered through an external stimulus unit or via a Labmaster interface driven by pClamp software (Axon Instruments) running on an AT-compatible computer.

\section{RESULTS}

The data presented below were obtained during intracellular recordings made from 119 supraoptic nucleus neurons impaled with sharp microelectrodes in superfused explants of rat hypothalamus. These cells had resting membrane potentials more negative than $-50 \mathrm{mV}$, input resistances $>100 \mathrm{M} \Omega$, and fired action potentials with amplitude that exceeded $60 \mathrm{mV}$ when measured from baseline. Each of these cells also displayed frequency-dependent spike broadening and transient outward rectification when examined from initial membrane potentials below $-75 \mathrm{mV}$. These combined characteristics have been shown to be specific to identified magnocellular neurosecretory neurons, but not to neighboring non-neuroendocrine cells, during intracellular recordings in vivo (Bourque and Renaud, 1991; Dyball et al., 1991).

\section{Effects of galanin on membrane potential}

Bolus infusion of GAL ${ }^{1-29}(50-1200 \mathrm{~nm})$ evoked a reversible membrane hyperpolarization $(1-14 \mathrm{mV})$ and inhibition of spike discharge in each of $14 \mathrm{MNCs}$ tested (Fig. $1 A$ ). Similar results were obtained by infusion of the $\mathrm{N}$-terminal fragment GAL $^{1-16}(50-1200 \mathrm{nM} ; n=30)$ (Fig. $\left.1 B\right)$ and of the chimeric GAL receptor ligands M40 (100-500 nM; $n=3)$ (Fig. 1C) and M35 (75-800 nM; $n=5$ of 9 cells tested). Although the onset of a hyperpolarizing response was usually detectable within 30 


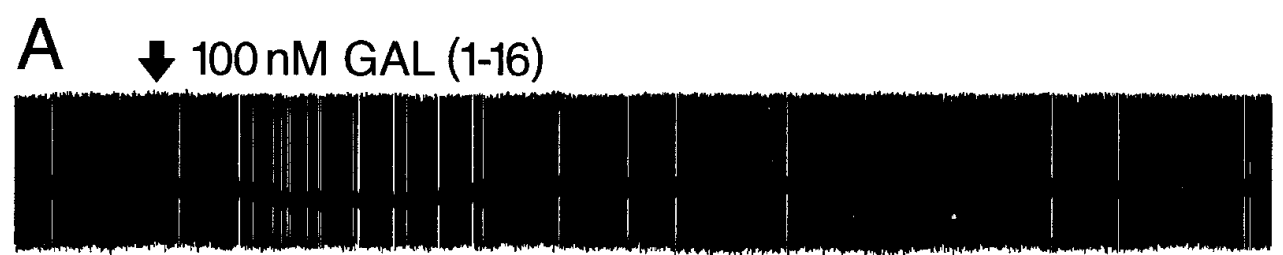

$250 \mathrm{nM}$

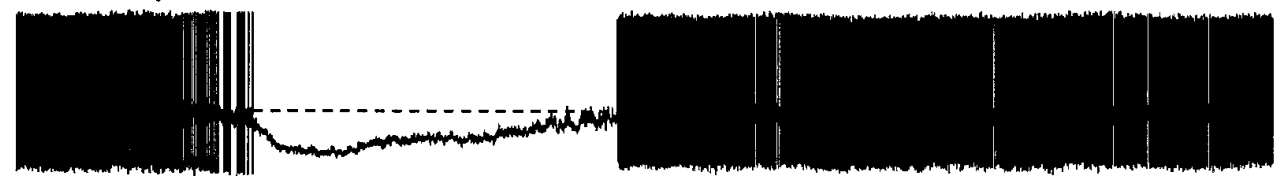

$500 \mathrm{nM}$
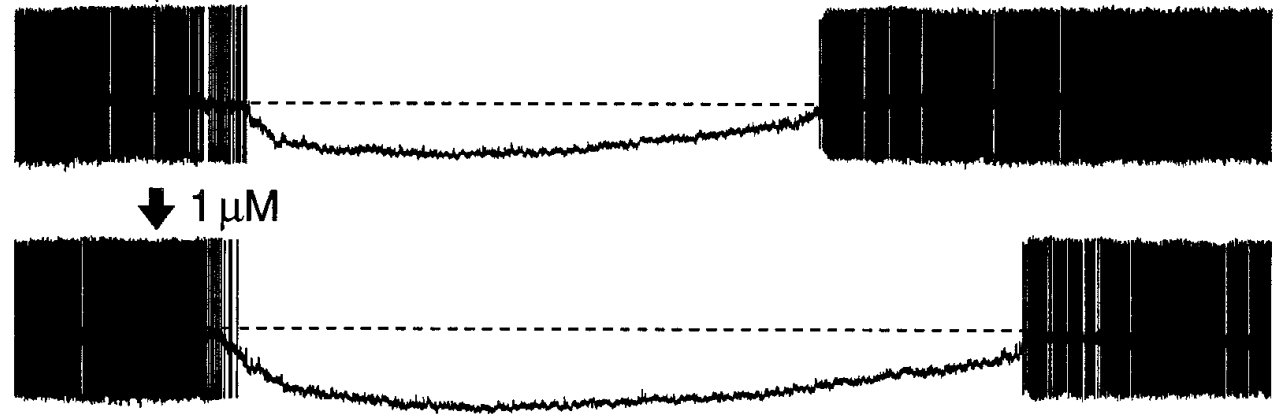

Figure 2. Comparison of the sensitivity of $\mathrm{MNCs}$ to $\mathrm{GAL}^{1-16}$ during transient and continuous delivery. $A$, Intracellularly recorded voltage responses (spike amplitudes in this and subsequent figures are attenuated by the chart recorder) of an $\mathrm{MNC}$ to brief infusions of $\mathrm{GAL}^{1-16}$ (10 sec, beginning at each arrow). Note that responses of increasing magnitude are evoked by increasing doses of the drug. $B$, Effect of applying a lower dose (20 nM, bar) of GAL ${ }^{1-16}$ by bath to a different MNC. Note that a longer delay occurs before the response and that continuous bath delivery greatly increases the effectiveness of the drug.

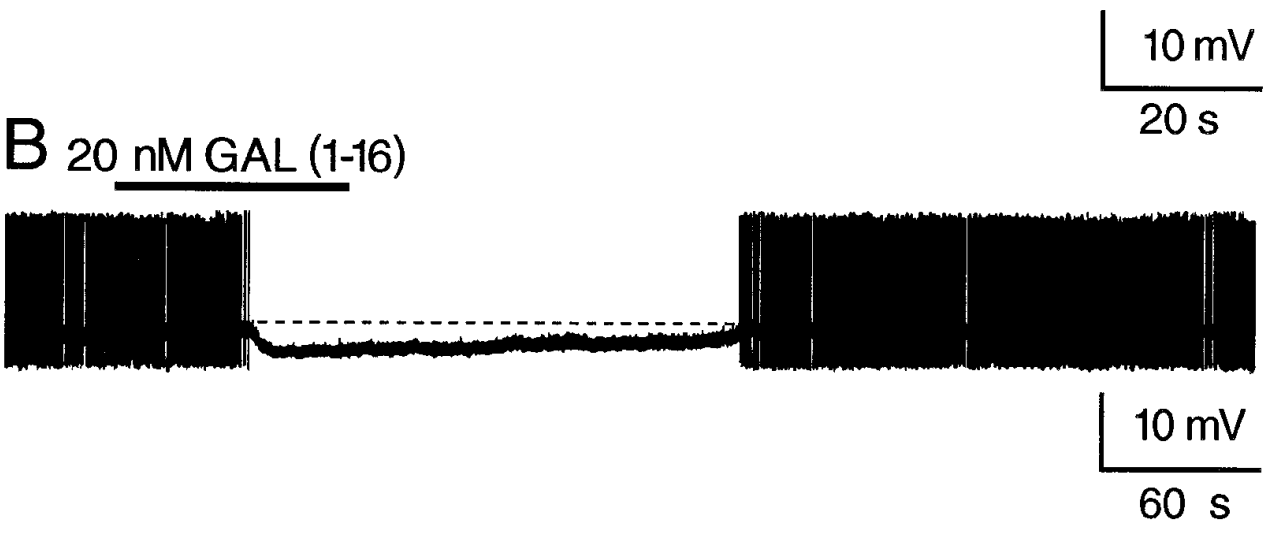

sec, the time required for full recovery was more variable (0.6-12 min), suggesting the involvement of a long-lived second messenger in mediating the effects of the neuropeptides. When tested in individual MNCs the effects of GAL ${ }^{1-16}$ were dose-dependent, showing an apparent threshold near $100 \mathrm{~nm}$ (Fig. 2A).

Similar to the effects evoked by transient bolus infusion, continuous $(30-120 \mathrm{sec})$ bath application of GAL ${ }^{1-16}$ evoked membrane hyperpolarization in 17 of 23 cells tested. These effects were also dose-dependent but occurred with an apparent threshold near $0.5 \mathrm{~nm}\left(\mathrm{IC}_{50}, \sim 10 \mathrm{~nm}\right)$, suggesting that the bioavailability of the peptides is about 200-fold lower during bolus inf usion than when applied by bath. Although the magnitude and course of onset of hyperpolarizing responses evoked by bath application were qualitatively similar to those evoked by bolus inf usions (Fig. $2 B$ ), the duration of the responses frequently exceeded $10 \mathrm{~min}$ on return to ACSF or were irreversible during the period of recording $(n=8)$. Except where indicated, therefore, the remainder of the analysis was performed on responses evoked by bolus drug delivery.

\section{Effects of galanin on membrane conductance}

The effects of GAL receptor activation on membrane conductance were examined in $18 \mathrm{MNCs}$ during repetitive application of brief $(160 \mathrm{msec})$ hyperpolarizing current pulses of constant amplitude. Based on changes in the size of the voltage responses to these current pulses, hyperpolarizing responses to $\mathrm{GAL}^{1-29}(n=$ 6) and $\mathrm{GAL}^{1-16}(n=12)$ (Fig. $\left.3 A\right)$ appeared to be accompanied by increases in mean \pm SEM membrane conductance of $19 \pm 4 \%$ and $17 \pm 2 \%$, respectively. These changes in input conductance were not attributable to the membrane hyperpolarization alone, because decreases in input resistance still occurred when membrane potential was held constant during the application of GAL ( $n=4$; data not shown). Hyperpolarizing responses and increases in membrane conductance induced by $\mathrm{GAL}^{1-16}$ were retained in the presence of $0.3 \mu \mathrm{M}$ tetrodotoxin $(n=4)$ (Fig. $3 B)$, suggesting that the receptors mediating these effects are expressed on the plama membrane of MNCs.

\section{Voltage-current analysis}

The reversal potential of responses evoked by GAL ${ }^{1-29}$ and $\mathrm{GAL}^{1-16}$ were determined by monitoring voltage responses to a 


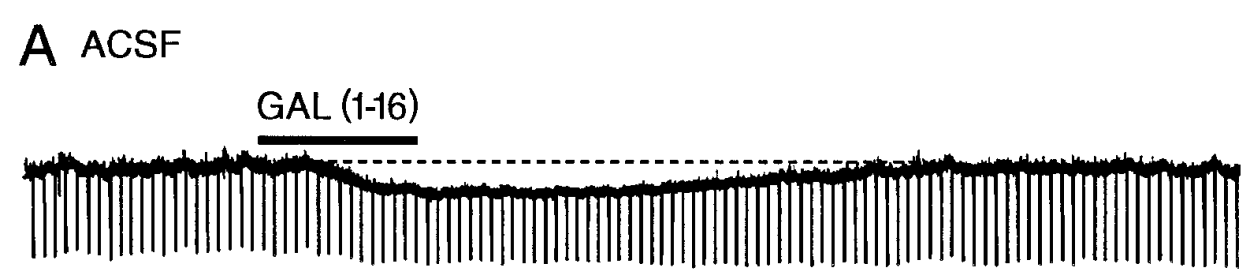

B ACSF + TTX

GAL (1-16)

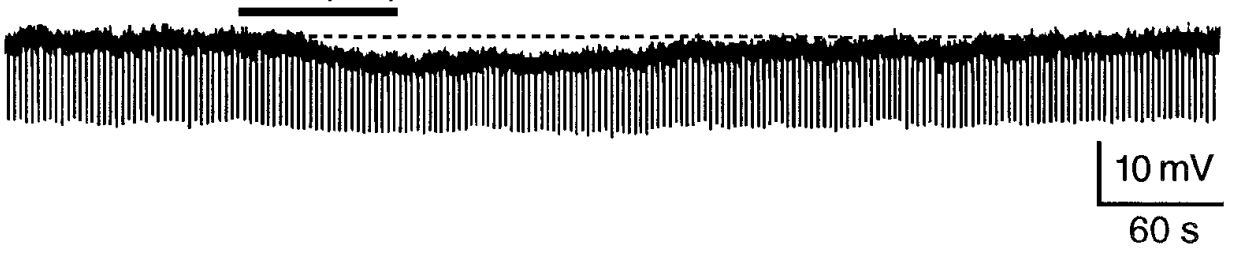

Figure 3. The effects of GAL are associated with an increase in membrane conductance. $A$, Effect of applying $500 \mathrm{~nm} \mathrm{GAL}^{1-16}$ (bar) to an $\mathrm{MNC}$ in the supraoptic nucleus. Downward deflections are electrotonic voltage responses to hyperpolarizing current pulses of constant amplitude (50 pA). The reduced amplitude of these deflections indicates that a $23 \%$ increase in membrane conductance is associated with the hyperpolarizing response. $B$, Recording obtained from a different cell showing that a similar response can be recorded when the explant is superfused with a solution containing $0.3 \mu \mathrm{M}$ tetrodotoxin $(T T X)$.

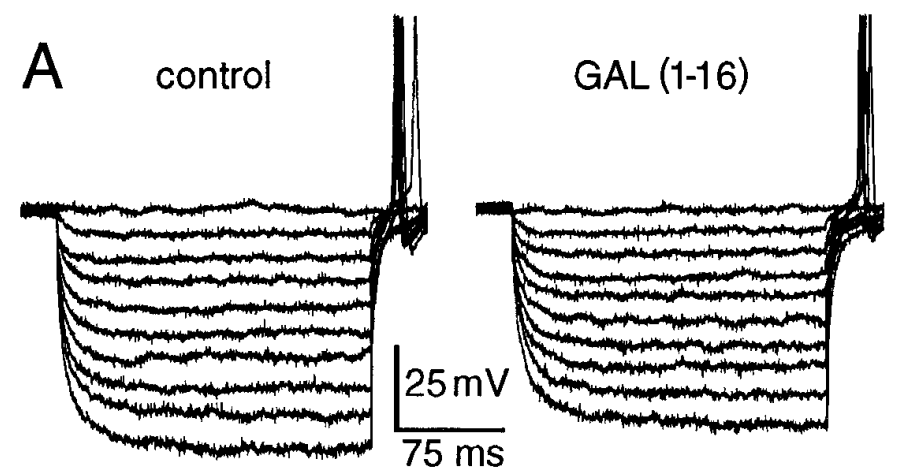

B

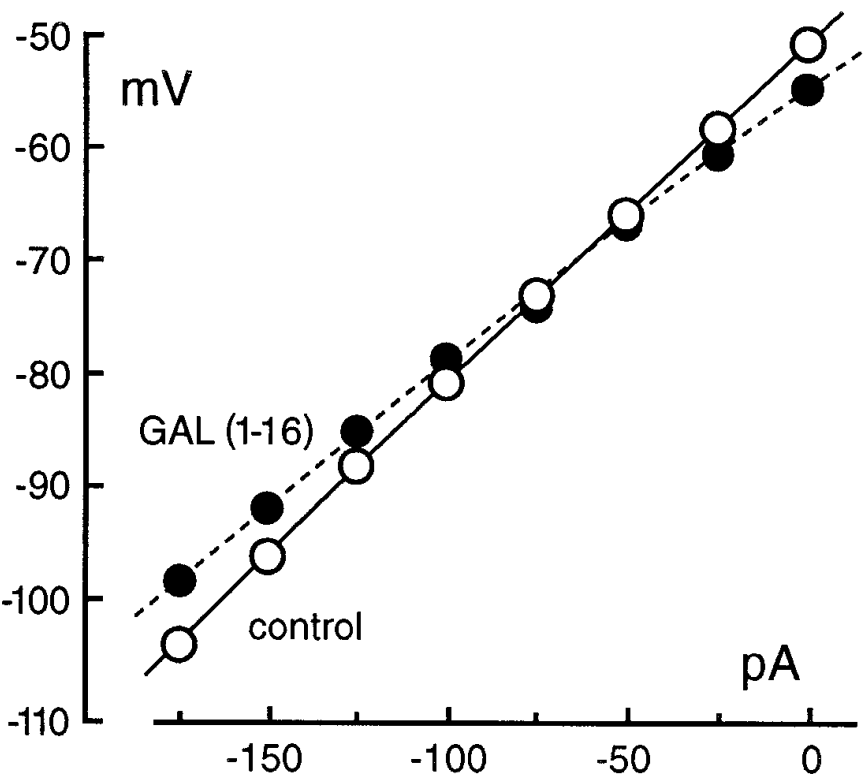

Figure 4. Reversal potential of the GAL-mediated hyperpolarization. $A$, Voltage responses to current steps (in $25 \mathrm{pA}$ increments) obtained before (control) and during bath application of $20 \mathrm{nM} \mathrm{GAL}^{1-16}$. In this experiment the cell hyperpolarized from a resting membrane potential of $-51 \mathrm{mV}$ (control) to $-55 \mathrm{mV}$ during $\mathrm{GAL}^{1-16}$ application (DC effect not shown). $B$, Membrane potential achieved during responses to current steps between 0 and $200 \mathrm{pA}$. Note that the reversal potential for GAL was near -70 . series of current steps generally eliciting electrotonic responses spanning voltages between -100 and $-50 \mathrm{mV}$. As illustrated in Figure 4, voltage-current (V-I) relationships measured in the presence and absence of agonist revealed an inversion point at a membrane potential negative to rest. Similar responses were observed whether the peptides were inf used as a bolus $(n=7)$ or delivered by bath $(n=5)$. The mean \pm SEM apparent reversal potentials of the responses were $-70 \pm 5 \mathrm{mV}$ for $\mathrm{GAL}^{1-29}(n=$ $7)$ and $-68 \pm 3 \mathrm{mV}$ for $\mathrm{GAL}^{1-16}(n=8)$. Because $\mathrm{GAL}^{1-29}$ and GAL $^{1-16}$ seem to affect supraoptic neurons in the same way, GAL $^{1-16}$ was used to probe the ionic basis of the underlying conductance.

\section{Effects of changes in intracellular and extracellular chloride concentration}

The reversal potential for GAL-mediated responses is close to the equilibrium potential for chloride ions under these recording conditions $\left(E_{\mathrm{Cl}}=-72 \mathrm{mV}\right)$ (Randle et al., 1986). We therefore examined the possibility that a $\mathrm{Cl}^{-}$conductance might be activated by GAL. Responses to GAL ${ }^{1-16}$ were recorded in eight cells impaled in explants superfused with a low $\left[\mathrm{Cl}^{-}\right] \mathrm{ACSF}$ and in five cells in which $\left[\mathrm{Cl}^{-}\right]_{\mathrm{i}}$ had been increased by intracellular injection. In each of these 13 cells it was confirmed that $\mathrm{E}_{\mathrm{Cl}}$ had shifted to a voltage positive to $-40 \mathrm{mV}$ by monitoring the amplitude and polarity of responses to GABA $(250 \mu \mathrm{M})$. Despite the clear inversion of the electrochemical gradient for chloride, relative to resting potential, evoked by these experimental manipulations, responses to $\mathrm{GAL}^{1-16}$ remained hyperpolarizing, with mean \pm SEM reversal potentials of $-71 \pm 3 \mathrm{mV}$ (increased $\left.\left[\mathrm{Cl}^{-}\right]_{\mathrm{i}}\right)$ and $-74 \pm 6 \mathrm{mV}\left(\right.$ low $\left.\left[\mathrm{Cl}^{-}\right]_{\mathrm{o}}\right)$.

\section{Effects of changes in extracellular $\mathrm{K}^{+}$concentration}

To examine the possible involvement of $\mathrm{K}^{+}$channels in mediating the effects of GAL agonists, voltage-current analysis was performed in five MNCs impaled in explants superfused with an ACSF in which the external concentration of $\mathrm{K}^{+}\left([\mathrm{K}]_{\mathrm{o}}\right)$ had been reduced from 3 to $1 \mathrm{~mm}$. Under these conditions, the amplitude of responses evoked by constant bolus infusions of GAL ${ }^{1-16}$ became progressively smaller when recorded from initial membrane potentials made progressively more negative by injection of constant current. In contrast to results observed in the presence of $3 \mathrm{~mm}$ $\left[\mathrm{K}^{+}\right]_{\mathrm{o}}$ (Fig. 4), however, responses did not reverse at potentials near $-70 \mathrm{mV}$ (Fig. 5A). Rather, V-I analysis of $\mathrm{GAL}^{1-16}$ - 
Figure 5. GAL-mediated hyperpolarizations are associated with an increase in $\mathrm{K}^{+}$conductance. $A$, Voltage responses to bolus infusions of $\mathrm{GAL}^{1-16}$ (1 $\mu \mathrm{M}$, arrows) recorded from a single $\mathrm{MNC}$ in ACSF containing $1 \mathrm{~mm}\left[\mathrm{~K}^{+}\right]_{\mathrm{o}}$. The steady membrane potential prevailing before each response (dashed line) was modified by sustained current injection. Note that responses evoked from progressively more negative membrane potentials become smaller in amplitude. $B$, Voltage-current relationships of this neuron measured before (control) and during a separate application of GAL $^{1-16}$ (not shown). Note that the reversal potential of the response $\left(E_{G A L}\right)$ is near $-90 \mathrm{mV}$.

A

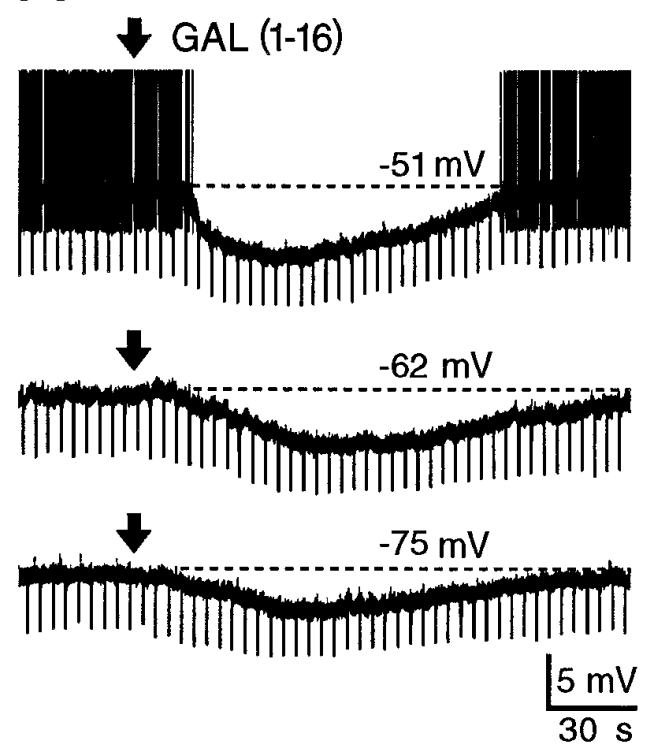

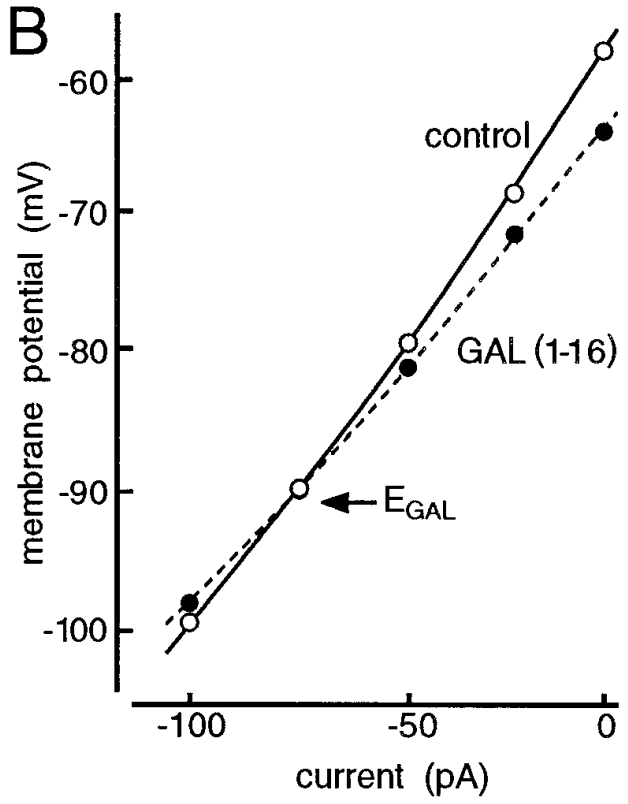

$\downarrow \operatorname{GAL}(1-16)$

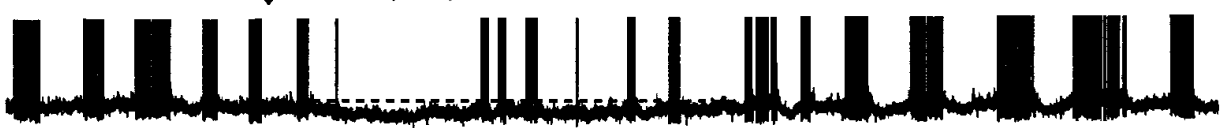

M35

Figure 6. GAL and M35 inhibit phasic activity in MNCs. Chart recordings show the effects of bolus infusion (arrows) of GAL ${ }^{1-16}(1$ $\mu \mathrm{M}$, top $)$ and M35 (0.5 $\mu \mathrm{M}$, bottom) on spontaneous activity in an MNC. Note that both drugs evoke a reversible membrane hyperpolarization associated with a decrease in activity.

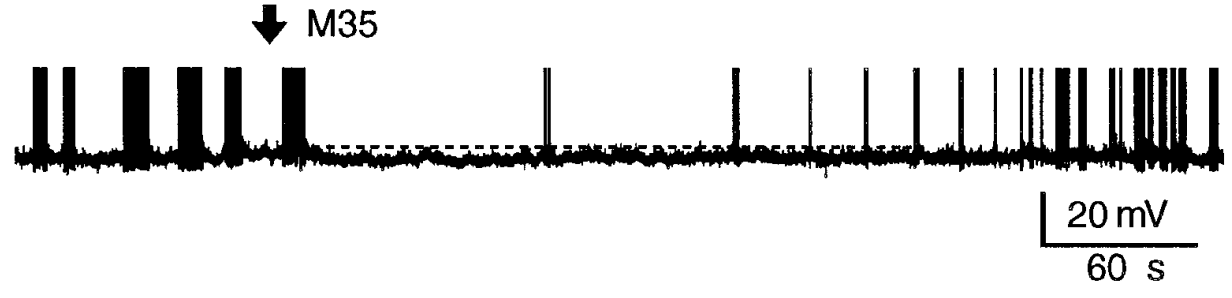

mediated responses recorded under such conditions revealed a mean \pm SEM reversal potential of $-85 \pm 4 \mathrm{mV}$.

\section{Effects of galanin on phasic activity and depolarizing afterpotentials}

Because the depolarizing afterpotential (DAP) that sustains phasic bursting activity in MNCs is voltage-dependent and is strongly attenuated by membrane hyperpolarization (Bourque, 1986; Bourque et al., 1997), we hypothesized that GAL would interfere with the generation of phasic firing. We therefore examined the effects of $\mathrm{GAL}^{1-16}$ on the activity of eight MNCs displaying spontaneous phasic firing. In seven of these cells, hyperpolarizing responses evoked by bolus administration of GAL $^{1-16}(0.25-1$ $\mu \mathrm{M})$ were associated with a reversible reduction of burst duration and with an increase in the duration of the silent intervals. These effects were mimicked by $\mathrm{GAL}^{1-29}(n=2)$ and by the chimeric ligand M35 $(n=2)$ (Fig. 6). To determine whether the inhibitory effects of GAL agonists on phasic bursting activity resulted from an attenuation of the DAP, we examined the effects of peptide infusion on DAPs evoked by brief $(50-80 \mathrm{msec})$ trains of constant numbers of action potentials evoked by current injection. In each of 12 MNCs tested, trains of three to six spikes evoked at intervals of 15-60 sec resulted in the generation of a constant DAP. Depending on the initial membrane potential of the cell, these trains elicited a subthreshold DAP $(n=6)$ or an afterdis- charge sustained by the plateau potential arising from the summation of consecutive DAPs $(n=6)$. In each case, hyperpolarizing responses to bolus applications of $\mathrm{GAL}^{1-16}$ were associated with a reversible and dose-dependent (threshold, $\sim 100 \mathrm{nM}$ ) reduction of the amplitude of the DAP or of the plateau potential that was evoked by each spike train (Fig. 7). To determine whether the potency of GAL ${ }^{1-16}$ on the DAP was similar to the effects of the peptide on membrane potential, we examined the effects of continuous bath application of GAL ${ }^{1-16}(75 \mathrm{pM}-1 \mu \mathrm{M})$ on post-train responses recorded from a constant initial membrane potential achieved by sustained current injection (Fig. 8). Under such conditions, GAL ${ }^{1-16}$ inhibited the DAP with an $\mathrm{IC}_{50}$ near $10 \mathrm{~nm}$, a value comparable to the effects of this peptide on membrane potential. Complete and reversible suppression of the DAP was consistently achieved during bath application of $\mathrm{GAL}^{1-16}$ at concentrations $\geq 300 \mathrm{~nm}$.

\section{DISCUSSION}

The findings reported here provide the first electrophysiological evidence that GAL can directly influence the electrical activity of MNCs in the rat supraoptic nucleus. Indeed, activation of GAL receptors promoted membrane hyperpolarization and inhibition of spike discharge in the vast majority of the neurons tested. Previous immunohistochemical studies have shown that approx- 

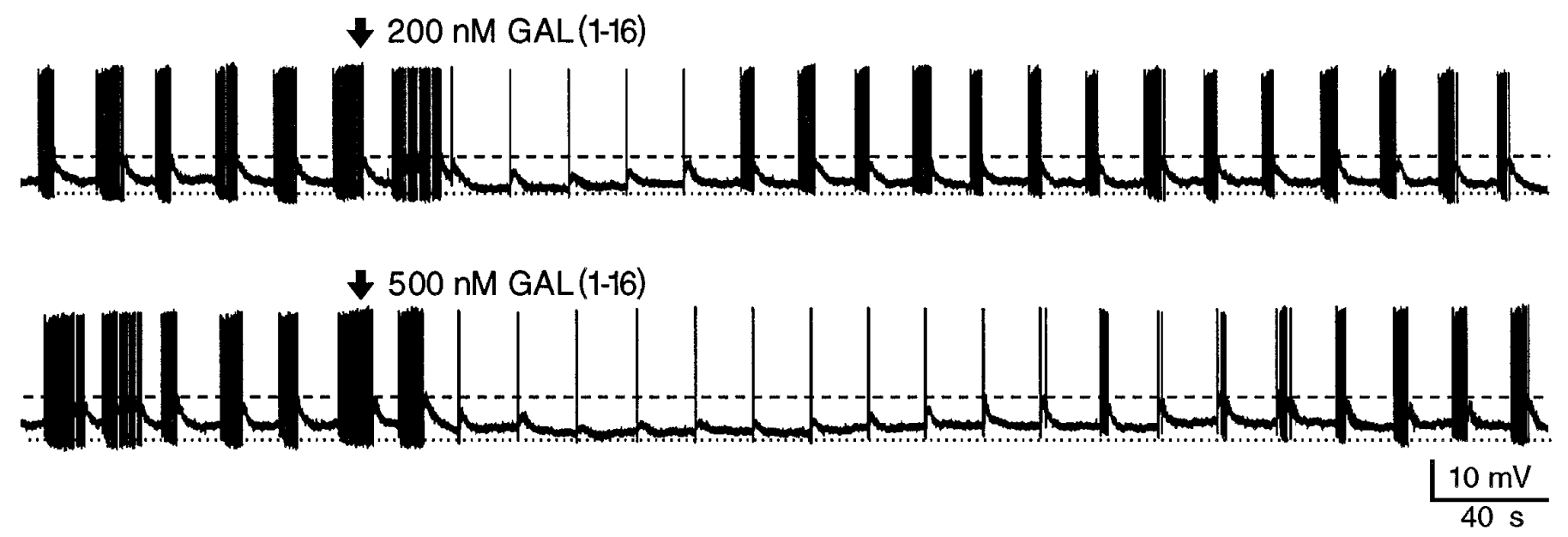

Figure 7. GAL depresses the postspike DAP and afterdischarges in MNCs. In this MNC (membrane voltage $=-50 \mathrm{mV}$, dashed line), brief depolarizing pulses eliciting four action potentials were given every $20 \mathrm{sec}$. Before the administration of GAL ${ }^{1-16}$ (arrows) each evoked train was followed by a large summed DAP eliciting an afterdischarge lasting 5-17 sec. As in previous figures, bolus injection of GAL ${ }^{1-16}$ resulted in a reversible membrane hyperpolarization (compare membrane voltage with dotted line). This effect, however, was accompanied by an inhibition of the afterdischarge resulting from an inhibition of the underlying DAP.

imately equal numbers of oxytocin- and vasopressin-containing MNCs are present in the supraoptic nucleus of the rat (e.g., Vandersande and Dierickx, 1975). Because the majority of neurons studied here were affected by the GAL-related ligands, it is likely that both types of MNCs express GAL receptors and could potentially be regulated by endogenously released GAL. Previously reported effects of intracerebroventricular GAL injections on oxytocin (Bjorkstrand et al., 1993) and vasopressin (Kondo et al., 1991; Kondo et al., 1993) release in vivo, therefore, might have been mediated via direct inhibition of action potential discharge at the somata of hypothalamic MNCs.

\section{Galanin hyperpolarizes MNCs via activation of $\mathbf{K}^{+}$conductance}

The inhibitory actions of GAL were unaffected by experimental manipulations causing an inversion in the electrochemical gradient for chloride ions relative to the resting potential. The effects of this peptide, therefore, presumably do not involve chloridepermeable channels. In contrast, reduction of the external concentration of potassium ions from 3 to $1 \mathrm{~mm}$ caused a hyperpolarizing shift of the reversal potential of responses to GAL ${ }^{1-16}$ from $-68 \mathrm{mV}$ to $-85 \mathrm{mV}$. Because hyperpolarizing responses were associated with an increase in membrane conductance, it is likely that a component of the GAL-mediated hyperpolarization resulted from the activation of $\mathrm{K}^{+}$channels. In agreement with this hypothesis, GAL has previously been reported to increase $\mathrm{K}^{+}$conductances in endocrine cells (de Weille et al., 1988; Dunne et al., 1989) as well as in autonomic (e.g., Konopka et al., 1989) and central neurons (e.g., Bartfai et al., 1991; Pieribone et al., 1995). The nature of the $\mathrm{K}^{+}$conductance involved in mediating the effects of GAL in MNCs remains to be established but could involve ATP-gated (de Weille et al., 1988; Dunne et al., 1989), tetraethylammonium-sensitive (Pieribone et al., 1995), or apamin-sensitive $\mathrm{K}^{+}$channels (Parsons and Konopka, 1990).

\section{Galanin inhibits DAPs and phasic firing}

In addition to hyperpolarizing effects mediated via the activation of $\mathrm{K}^{+}$conductance, GAL was found to be a potent inhibitor of the postspike DAP. The expression of the DAP in MNCs results in self-excitation and leads to the production of prolonged after- discharges after brief evoked trains of action potentials (Andrew and Dudek, 1984; Bourque, 1986; Bourque et al., 1997). Moreover, the presence of a DAP seems to be necessary for the production of phasic bursting activity (Armstrong et al., 1994), because manipulations that increase or decrease its magnitude respectively promote or abolish the occurrence of phasic firing (Li et al., 1995). Because this pattern of activity maximizes peptide hormone release from the neurohypophysis (Dutton and Dyball, 1979; Bicknell and Leng, 1981; Bicknell et al., 1982; Bicknell, 1988), the regulation of its expression through modulation of DAP amplitude represents an important cellular mechanism for regulating humoral output under different physiological or pathological conditions (Poulain and Wakerley, 1982).

Previous studies have indicated that histamine can potentiate the postspike DAP via the activation of postsynaptic $\mathrm{H}_{1}$ receptors (Smith and Armstrong, 1993). Because $\mathrm{H}_{1}$ receptor activation increases the phasic burst duration and intraburst firing rate (Armstrong and Sladek, 1985), histaminergic modulation of the DAP may participate in the promotion of phasic activity by enhancing DAPs. In contrast, the results presented here identify GAL as a potential inhibitory neuromodulator of phasic firing in the hypothalamo-neurohypophysial system of the rat. The existence of neurotransmitter systems exerting opposite actions on the magnitude of the DAP provides the CNS with a powerful mechanism for the afferent control of patterned activity in these neuroendocrine cells.

The mechanism by which the DAP is inhibited by GAL is unknown, as is the ionic nature of the DAP itself. Previous studies have indicated that the DAP is $\mathrm{Ca}^{2+}$-dependent (Bourque, 1986), requiring $\mathrm{Ca}^{2+}$ influx for its activation or expression (Li et al., 1995). Interestingly, GAL receptors have been shown to modulate voltage-gated calcium conductances (Homaidan et al., 1991; Kalkbrenner et al., 1995), thereby providing a possible mechanism by which GAL could modulate DAP amplitude. Indeed, the reversal potential of hyperpolarizing responses recorded in ACSF (approximately $-70 \mathrm{mV}$ ) did not correspond exactly to values previously determined to characterize $\mathrm{K}^{+}$currents recorded under similar conditions (e.g., $-97 \mathrm{mV}$ ) (Bourque, 1988). Moreover, the shift in reversal potential observed on re- 

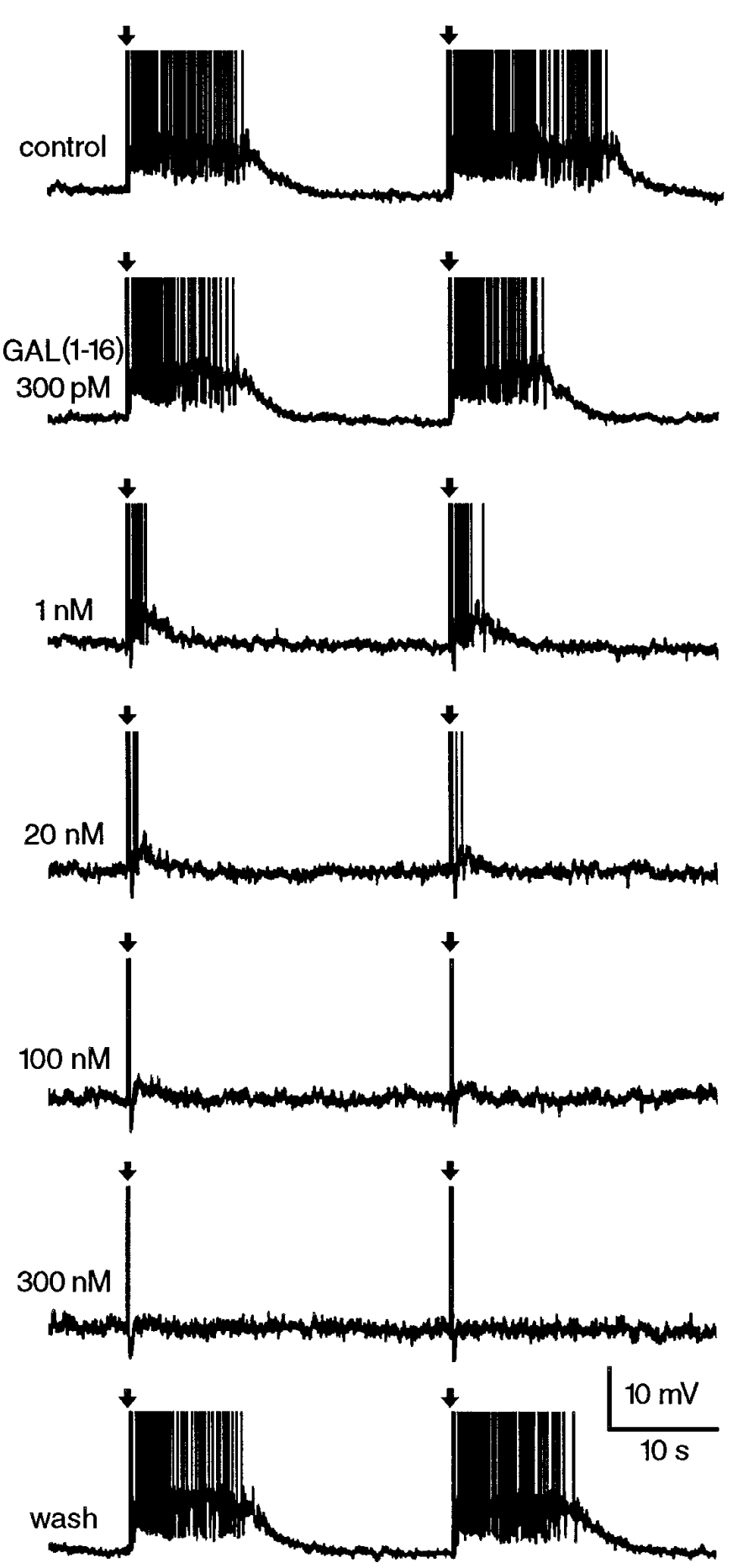

Figure 8. GAL inhibits the DAP independently of its effect on membrane voltage. In this cell, summed DAPs and afterdischarges after current-evoked trains comprising four action potentials (arrows) were monitored every $30 \mathrm{sec}$ from an initial membrane potential of $-60 \mathrm{mV}$ maintained by current injection. Note that the afterdischarges and DAPs are completely abolished at a dose of $300 \mathrm{~nm}$.

ducing external $\left[\mathrm{K}^{+}\right](17 \mathrm{mV})$ falls short of that predicted by the Nernst equation for a $\mathrm{K}^{+}$-selective conductance $(\sim 28 \mathrm{mV})$. These observations suggest that additional ionic mechanisms may indeed overlap the activation of a $\mathrm{K}^{+}$conductance on exposure to GAL. Whether voltage-gated $\mathrm{Ca}^{2+}$ currents are affected by GAL in MNCs remains to be established.

\section{GAL $^{1-16}$ and $\mathrm{GAL}^{1-29}$ are equipotent inhibitory modulators of MNCs}

Although only one GAL receptor is currently defined by molecular cloning (Habert-Ortoli et al., 1994; Gustafson et al., 1996), various subtypes of GAL receptors are thought to exist in the brain (Fisone et al., 1989; Hedlund et al., 1992, 1994; Wynick et al., 1993). Hedlund and colleagues $(1992,1994)$ have characterized a receptor in the brain that has a high affinity for $\mathrm{GAL}^{1-15}$ but will not bind GAL ${ }^{1-29}$. In addition, a GAL receptor exists in the anterior pituitary and hypothalamus that requires amino acids 3-10 and amino acid 25 of GAL for binding (Wynick et al., 1993). In our studies both GAL ${ }^{1-29}$ and $\mathrm{GAL}^{1-16}$ were found to be equipotent in their effects $\left(\mathrm{IC}_{50}, \sim 10 \mathrm{nM}\right)$, suggesting that neither of these receptor subtypes is involved in mediating the inhibitory actions of GAL on MNCs. The receptor activated here, however, seems to be similar to that described in the ventral hippocampus (Fisone et al., 1989), which recognizes both $\mathrm{GAL}^{1-29}$ and the $\mathrm{N}$-terminal fragment GAL ${ }^{1-16}$.

\section{The chimeric GAL analogs M35 and M40 are partial agonists}

The chimeric peptidergic GAL receptor analogs M35 (WiesenfeldHallin et al., 1992) and M40 (Crawley et al., 1993) have been shown to display a high affinity for GAL receptor sites and were initially reported to behave as GAL receptor antagonists (for review, see Bartfai et al., 1992). More recent studies, however, have indicated that M35 (Ogren et al., 1993; Kask et al., 1995) and M40 (Bartfai et al., 1993; Gu et al., 1993; Xu et al., 1995) can also behave as agonists in a variety of tissues. The electrophysiological data presented here indicate that at the concentrations tested M35 and M40 are indeed agonists of GAL receptors in MNCs of the supraoptic nucleus. Unless they are independently determined to lack agonist properties, therefore, the antagonistic effects observed in some biological systems might result from receptor desensitization during prolonged exposure or from simple occlusion.

\section{Possible sources and physiological functions of endogenous GAL}

Our results suggest that endogenously released GAL might play a role in the regulation of cell excitability and in the modulation of patterned activity in hypothalamic MNCs. Although the anatomical source of GAL fibers innervating MNCs in the supraoptic nucleus remains to be established, the extensive mapping studies by Melander et al. (1986) have demonstrated the presence of GALcontaining neurons in a wide variety of areas also known to contain neurons projecting to the supraoptic nucleus. Notably among these, large numbers of GAL-containing neurons are found in the periventricular tissue surrounding the preoptic recess of the third ventricle, a region known to play an important role in the regulation of MNCs (Bourque et al., 1994). Most intriguing, however, is the fact that MNCs themselves express high levels of GAL (Rökaeus et al., 1988; Skofitsch et al., 1989). Because these cells release neurosecretory products (vasopressin or oxytocin) from their somatodendritic regions (Morris et al., 1993), it is conceivable that they might also secrete physiologically relevant concentrations of GAL within the supraoptic nucleus. If this is the case, GAL release might serve a role in inhibitory feedback regulation of spike discharge in vasopressin- and oxytocin-releasing MNCs. Moreover, through its actions on the DAP, activity-dependent release of GAL might contribute to the termination of phasic bursts in vasopressinreleasing neurons. Additional studies will be required to investigate these possibilities. 


\section{REFERENCES}

Andrew RD, Dudek FE (1984) Analysis of intracellularly recorded phasic bursting by mammalian neuroendocrine cells. J Neurophysiol 51:552-566.

Armstrong WE, Sladek CE (1985) Evidence for excitatory actions of histamine on supraoptic neurons in vitro: mediation by an $\mathrm{H}_{1}$-type receptor. Neuroscience 16:307-322.

Armstrong WE, Smith BN, Tian M (1994) Electrophysiological characteristics of immunochemically identified rat oxytocin and vasopressin neurones in vitro. J Physiol (Lond) 475:115-128.

Bartfai T, Bedecs K, Land T, Langel U, Bertorelli R, Girotti P, Consolo $\mathrm{S}, \mathrm{Xu} \mathrm{X}$, Wiesenfeld-Hallin Z, Nilsson S, Pieribone VA, Hokfelt T (1991) M-15: high-affinity chimeric peptide that blocks the neuronal actions of galanin in the hippocampus, locus coeruleus, and spinal cord. Proc Natl Acad Sci USA 88:10961-10965.

Bartfai T, Fisone G, Langel U (1992) Galanin and galanin antagonists: molecular and biochemical perspectives. Trends Pharmacol Sci 13:312-317.

Bartfai T, Langel U, Bedecs K, Andell S, Land T, Gregersen S, Ahren B, Girotti P, Consolo S, Corwin R, Crawley J, Xu X, Wiesenfeld-Hallin Z, Hokfelt T (1993) Galanin-receptor ligand M40 peptide distinguishes between putative galanin-receptor subtypes. Proc Natl Acad Sci USA 90:11287-11291.

Bicknell RJ (1988) Optimizing release from peptide hormone secretory nerve terminals. J Exp Biol 139:51-65.

Bicknell RJ, Leng G (1981) Relative efficiency of neural firing patterns for vasopressin release in vitro. Neuroendocrinology 33:295-299.

Bicknell RJ, Flint APF, Leng G, Sheldrick EL (1982) Phasic pattern of electrical stimulation enhances oxytocin secretion from the isolated neurohypophysis. Neurosci Lett 30:47-50.

Bjorkstrand E, Hulting AL, Meister B, Uvnas-Moberg K (1993) Effect of galanin on plasma levels of oxytocin and cholecystokinin. NeuroReport $4: 10-12$.

Bourque CW (1986) Calcium-dependent spike after-current induces burst firing in magnocellular neurosecretory cells. Neurosci Lett 70:204-209.

Bourque CW (1988) Transient calcium-dependent potassium current in magnocellular neurosecretory cells of the rat supraoptic nucleus. J Physiol (Lond) 397:331-347.

Bourque CW (1989) Ionic basis for the intrinsic activation of rat supraoptic neurones by hyperosmotic stimuli. J Physiol (Lond) 417:263-277.

Bourque CW (1990) Intraterminal recordings from the rat neurohypophysis in vitro. J Physiol (Lond) 421:247-262.

Bourque CW, Renaud LP (1991) Membrane properties of rat magnocellular neuroendocrine cells in vivo. Brain Res 540:349-352.

Bourque CW, Oliet SHR, Richard D (1994) Osmoreceptors, osmoreception, and osmoregulation. Front Neuroendocrinol 15:231-274.

Bourque CW, Kirkpatrick K, Jarvis CR (1998) Extrinsic modulation of spike afterpotentials in rat hypothalamo-neurohypophysial neurons. Cell Mol Neurobiol, in press.

Crawley JN, Robinson JK, Langel U, Bartfai T (1993) Galanin receptor antagonists M40 and C7 block galanin-induced feeding. Brain Res 600:268-272.

de Weille J, Schmid-Antomarchi H, Fosset M, Lazdunski M (1988) ATP-sensitive $\mathrm{K}^{+}$channels that are blocked by hypoglycemia-inducing sulfonylureas in insulin-secreting cells are activated by galanin, a hyperglycemia-inducing hormone. Proc Natl Acad Sci USA 85:1312-1316.

Dreifuss JJ, Kalnins I, Kelly JS, Ruf KB (1971) Action potentials and release of neurohypophysial hormones in vitro. J Physiol (Lond) 215:805-817.

Dunne MJ, Bullett MJ, Li G, Wollheim CB, Petersen OH (1989) Galanin activates nucleotide-dependent $\mathrm{K}^{+}$channels in insulin-secreting cells via a pertussis toxin-sensitive G-protein. EMBO J 8:413-420.

Dutton DA, Dyball REJ (1979) Phasic firing enhances vasopressin release from the rat neurohypophysis. J Physiol (Lond) 290:433-440.

Dyball REJ, Tasker J-G, Wuarin J-P, Dudek FE (1991) In vivo intracellular recording of neurons in the supraoptic nucleus of the rat hypothalamus. J Neuroendocrinol 3:383-386.

Fisone $\mathrm{G}$, Berthold M, Bedecs K, Unden A, Bartfai T, Bertorelli R, Consolo S, Crawley J, Martin B, Nilsson S, Hokfelt T (1989) N-terminal galanin-(1-16) fragment is an agonist at the hippocampal galanin receptor. Proc Natl Acad Sci USA 86:9588-9591.

Gaymann W, Martin R (1989) Immunoreactive galanin-like material in magnocellular hypothalamo-neurohypophysial neurones of the rat. Cell Tissue Res 255:139-147.

Gu Z-F, Rosswoski WJ, Coy DH, Pradhan TK, Jensen RT (1993) Chimeric galanin analogs that function as antagonists in the CNS are full agonists in gastrointestinal smooth muscle. J Pharmacol Exp Ther 266:912-918.

Gustafson EL, Smith KE, Durkin MM, Gerald C, Branchek TA (1996) Distribution of a rat galanin receptor mRNA in rat brain. NeuroReport 7:953-957.

Habert-Ortoli E, Amiranoff B, Loquet I, Laburthe M, Mayaux J-F (1994) Molecular cloning of a functional human galanin receptor. Proc Natl Acad Sci USA 91:9780-9783.

Hedlund PB, Yanaihara N, Fuxe K (1992) Evidence for specific $\mathrm{N}$-terminal galanin fragment binding sites in the rat brain. Eur J Pharmacol 224:203-205.

Hedlund PB, Finnman U-B, Yanaihara N, Fuxe K (1994) Galanin-(1$15)$, but not galanin-(1-29), modulates $5-\mathrm{HT}_{1 \mathrm{~A}}$ receptors in the dorsal hippocampus of the rat brain: possible existence of galanin receptor subtypes. Brain Res 634:163-167.

Homaidan FR, Sharp GWG, Nowak LM (1991) Galanin inhibits a dihydropyridine-sensitive $\mathrm{Ca}^{2+}$ current in the RINm5f cell line. Proc Natl Acad Sci USA 88:8744-8748.

Kalkbrenner F, Degtiar VE, Schenker M, Brendel S, Zobel A, Heschler J, Wittig B, Schultz G (1995) Subunit composition of $G_{o}$ proteins functionally coupling galanin receptors to voltage-gated calcium channels. EMBO J 14:4728-4737.

Kask K, Berthold M, Bourne J, Andell S, Langel U, Bartfai T (1995) Binding and agonist/antagonist actions of M35, galanin(1-13)-bradykinin(2-9)amide chimeric peptide, in Rin $\mathrm{m} 5 \mathrm{~F}$ insulinoma cells. Regul Pept 10:341-348.

Kondo K, Murase T, Otake K, Ito M, Oiso Y (1991) Centrally administered galanin inhibits osmotically stimulated arginine vasopressin release in conscious rats. Neurosci Lett 128:245-248.

Kondo K, Murase T, Otake K, Ito M, Kurimoto F, Oiso Y (1993) Galanin as a physiological neurotransmitter in hemodynamic control of arginine vasopressin release in rats. Neuroendocrinology 57:224-229.

Konopka LM, McKeon TW, Parsons RL (1989) Galanin-induced hyperpolarization and decreased membrane excitability of neurones in mudpuppy cardiac ganglia. J Physiol (Lond) 410:107-122.

Landry M, Roche D, Calas A (1995) Short-term effects of centrally administered galanin on the hyperosmotically stimulated expression of vasopressin in the rat hypothalamus. An in situ hybridization and immunohistochemistry study. Neuroendocrinology 61:393-404.

Levin MC, Sawchenko PE, Howe PRC, Bloom SR, Polak JM (1987) Organization of galanin-immunoreactive inputs to the paraventricular nucleus with special reference to their relationship to catecholaminergic afferents. J Comp Neurol 261:562-582.

Li Z, Decavel C, Hatton GI (1995) Calbindin- ${ }_{28 k}$ : role in determining intrinsically generated firing patterns in rat supraoptic neurones. J Physiol (Lond) 488:601-608.

Melander T, Hökfelt T, Rökaeus A (1986) Distribution of galaninlike immunoreactivity in the rat central nervous system. J Comp Neurol 248:475-517.

Morris JF, Pow DV, Sokol HW, Ward A (1993) Dendritic release of peptides from magnocellular neurons in normal rats, Brattleboro rats and mice with hereditary nephrogenic diabetes insipidus. In: Vasopressin (Gross P, Richter D, Robertson GL, eds), pp 171-182. London: Libbey. Ogren SO, Pramanik A, Land T, Langel U (1993) Differential effects of the putative galanin receptor antagonists M15 and M35 on striatal acetylcholine release. Eur J Pharmacol 242:59-64.

Parsons RL, Konopka LM (1990) Galanin-induced hyperpolarization of mudpuppy neurons is calcium dependent. Neurosci Lett 115:207-212.

Pieribone VA, Xu ZQ, Zhang X, Grillner S (1995) Galanin induces a hyperpolarization of norepinephrine-containing locus coeruleus neurons in the brainstem slice. Neuroscience 64:861-874.

Poulain DA, Wakerley JB (1982) Electrophysiology of hypothalamic magnocellular neurones secreting oxytocin and vasopressin. Neuroscience 7:773-808.

Randle JCR, Bourque CW, Renaud LP (1986) Characterization of spontaneous and evoked inhibitory postsynaptic potentials in rat supraoptic neurosecretory neurons in vitro. J Neurophysiol 56:1703-1717.

Rökaeus A, Young III WS, Mezey E (1988) Galanin coexists with vasopressin in the normal hypothalamus and galanin's synthesis is increased in the Brattleboro (diabetes insipidus) rat. Neurosci Lett 90:45-50.

Skofitsch G, Jacobowitz DM, Amann R, Lembek F (1989) Galanin and 
vasopressin coexist in the rat hypothalamo-neurohypophyseal system. Neuroendocrinology 49:419-427.

Smith BN, Armstrong WE (1993) Histamine enhances the depolarizing afterpotential of immunohistochemically identified vasopressin neurons in the rat supraoptic nucleus via $\mathrm{H}_{1}$-receptor activation. Neuroscience 53:855-864.

Striker EM, Verbalis JG (1986) Interaction of osmotic and volume stimuli in the regulation of neurohypophysial secretion in rats. Am J Physiol 250:R267-R275.

Summerlee AJS (1981) Extracellular recordings from oxytocin neurones during the expulsive phase of birth in unanaesthetized rats. J Physiol (Lond) 321:1-9.

Tatemoto K, Rökaeus A, Jörnvall H, McDonald TJ, Mutt V (1983) Galanin-a novel biologically active peptide from porcine intestine. FEBS Lett 164:124-128.

Vandersande F, Dierickx K (1975) Identification of the vasopressin producing and of the oxytocin producing neurons in the hypothalamic magnocellular neurosecretory system of the rat. Cell Tissue Res 164: $153-162$.
Verbalis JG, Dohanics J (1991) Vasopressin and oxytocin secretion in chronically hypoosmolar rats. Am J Physiol 261:R1028-R1038.

Verbalis JG, Mangione MP, Striker EM (1991) Oxytocin produces natriuresis in rats at physiological plasma concentrations. Endocrinology 128:1317-1322.

Wakerley JB, Lincoln DA (1973) The milk ejection reflex of the rat: a 20 -to 40 -fold acceleration in the firing of paraventricular neurones during oxytocin release. J Endocrinol 57:477-493.

Wiesenfeld-Hallin Z, Xu XJ, Langel U, Bedecs K, Hokfelt T, Bartfai T (1992) Galanin mediated control of pain: enhanced role after nerve injury. Proc Natl Acad Sci USA 89:3334-3337.

Wynick D, Smith DM, Ghatei M, Akinsanya K, Bhogal R, Purkiss P, Byfield P, Yanaihara N, Bloom SR (1993) Characterization of a highaffinity galanin receptor in the rat anterior pituitary: absence of biological effect and reduced membrane binding of the antagonist M15 differentiate it from the brainn/gut receptor. Proc Natl Acad Sci USA 90:4231-4235.

Xu XJ, Wiesenfeld-Hallin Z, Langel U, Bedecs K, Bartfai T (1995) New high affinity peptide antagonists to the spinal galanin receptor. $\mathrm{Br} \mathbf{J}$ Pharmacol 116:2076-2080. 